\title{
Сергій Корольов
}

Льотна академія Національного авіаційного університету ORCID ID 0000-0003-0206-6794

DOI 10.24139/2312-5993/2020.02/099-110

\section{РОЗВИТОК МЕТОДИКИ ВИКЛАДАННЯ МЕХАНІКИ ЯК БОРОТЬБА ВАРІАТИВНОГО ТА НЬЮТОНІВСЬКОГО ПІДХОДІВ}

Чергова стаття з циклу, присвяченому покращенню методики викладання механіки. Пропонується новий комплексний підхід викладання механіки, який базується на діалектичному застосуванні багатомірного масиву з декількох базових засад, які комбінуються між собою, у залежності від конкретної ситуації в викладанні, створюючи широке поле можливостей. До рівня «minimum minimorum» масиву засад пропонується включити розгляд розвитку механіки як боротьби та співпраці підходів Ньютона, який використовує узагальнення великої кількості спостережень та дослідів, і варіативних підходів Лагранжа та Гамільтона, які беруть свій початок фактично в оптиці і являють собою вдало вгаданий постулат.

Показано, що одночасне використання декількох підходів буде сприяти покращенню методики.

Ключові слова: методика викладання механіки, варіативний підхід, метод Лагранжа, метод Гамільтона, діалектична взаємодія, парадигма Ньютона.

Постановка проблеми. Давно зрозуміло, що наш час та суспільство характеризуються значним ростом вимог до рівня кваліфікації випускників закладів вищої освіти. Значну роль в одержанні кваліфікаційних знань та вмінь у випускників має вивчення технічної механіки. Тому дуже важливо вдосконалити методику викладання механіки шляхом широкого застосування нових та нестандартних підходів.

Аналіз актуальних досліджень. Автору статті невідомі більш ранні публікації, які розглядають навчальний процес із вивчення механіки як єдиний діалектичний комплекс із вивчення законів природи на базі механіки, що першим у світі спробував зробити Ньютон у своїх працях. До мінімального списку складових механістичного підходу можна віднести такі: теорію інформації; комп'ютерні технології; метод математичних моделей; стандартна методика викладання механіки; урахування історичної еволюції базових понять механіки; парадигма Ньютона; підхід Лагранжа; підхід Гамільтона.

На думку автора, необхідно прикладати зусилля як викладачам під час вивчення механіки, так і студентам. Поєднання цих зусиль повинне дати мультиплікативний ефект, тобто загальний ефект буде значно більшим, ніж просто арифметична сума складових.

Треба правильно врахувати той факт, що кожен студент має свій набір сильних та слабих сторін, тому підхід до ефективного вивчення механіки повинен бути тільки індивідуальним. 
Одними з перших робіт, у яких робився наголос на індивідуальній роботі зі студентами та врахування їх особливостей, були такі:

А. С. Граніцкая запропонувала створити адаптивну систему навчання, у якій треба дорогоцінний час уроку ділити поміж різними учнями в залежності від їх здібностей (Границкая, 1991). В.К. Д'яченко створив та впровадив у дію систему керування структурою навчального процесу в залежності від конкретної ситуації (Дьяченко, 1989). Н.Ф. Тализіна запропонувала вчителю гнучко керувати процесом засвоювання знань учнями в залежності від здібностей учнів (Талызина, 1975). І. Е. Унт створила систему диференціації навчання в залежності від здібностей учнів, у якій основна частка роботи припадає на індивідуальну роботу 3 учнями (Унт, 1990). В.Д. Шадріков висунув ідею класів змінного складу учнів по кожній навчальній дисципліні, що приведе до конкуренції між вчителями за учнів (Шадриков, 2014).

Мета статті - привернути увагу педагогів до нових можливостей, які виникають у викладанні механіки внаслідок використання ідеї Ньютона про дослідження природи шляхом створення механістичних моделей складних явищ. Пропонується скористатися підходами Лагранжа та Гамільтона, додержуватися діалектичного підходу, коли в органічній єдності співпрацюють та підсилюють один одного декілька різних напрямів у науці, що дасть також покращення розуміння механіки.

Методи дослідження. Застосовується метод послідовних наближень та метод порівняльного аналізу, за яких одержані результати поступово ускладнюються та наближаються до реальності. Використовується метод запозичення понять із інших наук, що дозволяє застосовувати більш розроблені розділи інших наук у менш опрацьованих розділах науки.

Виклад основного матеріалу. Ньютон залишив яскравий слід у природознавстві, як ніхто інший. Подальший розвиток науки про природу йшов у постійному діалозі з ним: або продовжуючи його ідеї, приблизно до початку XX століття, або заперечував їх у більш пізню епоху (Ньютон, 1989).

Досягнення Ньютона полягає в тому, що він сформулював дослідницьку програму вивчення природи на базі механіки, яку потім стали реалізовувати інші вчені протягом довгого часу (Декарт, 1989).

Спочатку була створена фундаментальна механіка Ньютона, потім ії доопрацювали до рівня абстрактної базової теорії, як, наприклад, аналітичну механіку Лагранжа. Подальший розвиток аналітичної механіки привів до того, що множина її інформації стала багато в чому спільною $з$ множинами інформації в аеродинаміці, гідродинаміці, будівельній механіці та інших напрямах. Відповідно до законів діалектики розвитку складних структур на перетині множин різних наукових дисциплін, відбувся експоненціальний зріст об'єму нової наукової інформації (История механики с конца XVIII века до середины XX века, 1972). 
Механіка Ньютона належить до теорій аксіоматичного типу, в ії базис входить низка фундаментальних понять та принципів. За допомогою дедукції та диференційних рівнянь другого порядку формулюються закони (наслідки).

Йому вдалося в межах механічної дослідницької програми запропонувати універсальні закони та принципи, які працюють як у фундаментальних, так і в конкретних програмах різних напрямів. Це можна пояснити тим фактом, що механічна програма була не тільки першою в світі дослідницькою програмою, але й довгий час єдиною науковою програмою. Це дало можливість у межах механічної програми досягти певної методологічної та концептуальної єдності. Як результат, у межах механічної програми були запропоновані та в подальшому розвинені різні теорії, які внаслідок свого розвитку згодом значно вийшли за межі механіки.

Механіка Ньютона базується на законах руху, які описуються диференційними рівняннями. Це значить, що матеріальне тіло рухається від однієї точки простору до іншої, що дає можливість розрахувати положення тіла в наступний момент, якщо відомі координати тіла в попередній момент часу. Видно, що в цьому пункті закони Ньютона значно відрізняються від положень його попередників.

у заслугу Ньютону можна поставити глибоке розуміння диференційного характеру законів руху, які він відкрив. Саме диференційний характер законів можна назвати найбільш вдалою формою пояснення причино-наслідкового зв'язку.

Ясно, що існує конкуренція між аксіоматичним підходом Ньютона в побудові механіки та екстремальними принципами механіки Лагранжа й механіки Гамільтона. Аксіоматичний підхід Ньютона базується на узагальнені тисяч дослідів різних учених, зроблених у різний час у різних точках багатовимірного простору-часу. Їх можна піддати перевірці кожному досліднику, хто має сумніви, цим цей підхід імпонує автору. Екстремальні принципи Лагранжа та Гамільтона з'явилися в механіці шляхом запозичення з оптики. Їх обґрунтування досить непереконливе, фактично вони виступають як постулат природи, який вдало вгадали. Ферма запропонував, свого часу, свій варіант екстремального принципу, який, разом із тим, суперечив принципам механіки Ньютона. Спроби побудувати механіку на принципі найменшої дії були в Ейлера (Эйлер, 1934) та Мопертюї, але їх не можна назвати вдалими.

Механіцизм на своєму початку дав імпульс поясненню багатьох явищ природи з точки зору механіки. Але потім його потенціал закінчився і на шляху розвитку природознавства з'явилося багато явищ, які було неможливо пояснити з точки зору механіки.

Виникає проблема - яким чином визначити: які явища належать до механіки, а які - не належать. 3 аналізу вище згаданої інформації механіку можна визначити як науку, що вивчає найпростіші форми руху матеріальних 
тіл, зміну координат тіл у просторі з плином часу, зміну взаємного положення якогось тіла відносно інших та умови рівноваги системи тіл. У механічних системах масив швидкостей та масив координат тіл системи, якщо вони відомі в певний момент часу, однозначно визначають еволюцію цієї системи на майбутнє для будь-якого моменту часу. Сили будуть залежати від координат тіл, їх швидкостей та від часу. У межах існуючих модельних уявлень будь-яку систему матеріальних тіл можна замінити на систему матеріальних точок. Вони взаємодіють між собою за принципом віддаленої дії, тобто швидкість передачі сил на відстань $€$ нескінченно великою. Відомо, що в реальності максимальна швидкість руху матеріальних тіл не може зрівнятися зі швидкістю електромагнітної хвилі у вакуумі, що є протиріччям. Виникає питання - у яких випадках ми маємо право використовувати механічний підхід за межами механіки? Зрозуміло, що кордони між механікою та їі спорідненими дисциплінами дуже умовні й залежать від точки зору конкретного вченого. Якщо розглядати рух великої молекули, наприклад, білка, з невеликою швидкістю, то закони механіки дадуть правильну відповідь, а якщо це будуть молекули водню, їх буде багато і швидкість буде значною, то треба буде використовувати або термодинаміку, або теорію відносності.

Даламбер спробував побудувати механіку на принципах, відмінних від принципів Ньютона. Даламбер пропонував проблеми динаміки, на визначення законів руху, зводити до задач статики, яка розглядає випадок нерухомих тіл. Для цього він пропонує додавати в систему діючих сил деякі фіктивні додаткові сили. Ця пропозиція була дуже сміливою, далеко не всі вчені її прийняли.

Даламбер ще не чітко розумів термін «прискорення», у нього були 3 цим проблеми, не всі мислителі чітко розділяли інерцію і силу інерції того часу, це був час створення та «шліфування» базових понять механіки (Веселовский, 1974).

Лагранж продовжив розвиток аналітичної механіки з метою звести механіку й методи вирішення її завдань до формул загального виду, з яких потім отримують усі необхідні рівняння для кожного конкретного завдання. Він прагнув не робити креслень до задач, хоча загальновідомо $з$ практики викладання, що добре виконане креслення - це половина вирішення завдання. Звідси видно, що його можна вважати більше математиком, ніж механіком.

Кажучи сучасною мовою, мислитель розробив загальні рівняння руху голономної механічної системи зі скінченим числом ступенів свободи матеріальних тіл. Ці рівняння дали змогу звести вирішення будь-якої задачі на визначення руху механічної системи до взяття інтегралів від диференційних рівнянь. На його думку, таким чином механіка стала частиною чистого математичного аналізу. Система рівнянь дала змогу 
складати рівняння руху складних систем матеріальних тіл за єдиним зразком. Проблема стала математичною - треба було вміти інтегрувати різноманітні диференційні рівняння.

Учений займався також астрономією, розглядаючи їі фактично як механіку небесних тіл.

Мислитель механіку розвивав як науку, що складається з двох частин статика і динаміка, до нього статика та динаміка вважалися абсолютно різними дисциплінами, він ці розділи механіки звів в одну дисципліну. Статикою він називав науку про рівновагу сил. Лагранж вивів рівняння рівноваги гнучкої нитки та одержав умови рівноваги ідеальної рідини.

Учений використовував для позначення сили терміни «force» та «potentia», під ними розумілася будь-яка причина, яка намагалась зрушити й надати швидкість матеріальному тілу, до якого вона була прикладена. Ці терміни Лагранж майже не розділяв, частіше «рotentia» використовував для позначення сили, що рухає тіло. Він також використовував поняття «ударні сили». Це говорить про неповне розуміння ним проблеми.

Кінематику він не виділив, хоча в сучасних курсах механіки розділ «Кінематика» завжди присутній. Незважаючи на свої досягнення та успіхи в механіці, він так і не зумів ввести поняття «прискорення» в теперішньому значенні, це заслуга інших учених. Лагранж під поняттям «прискорення» розумів силу, яка діє на тіло одиничної маси, що формально збігається з 2м законом Ньютона в сучасних термінах.

Він вводить дуже важливе поняття в механіку - принцип віртуальних переміщень, (який спочатку був ним названий принципом віртуальних швидкостей), тобто таких переміщень, які можливі в конкретній системі 3 урахуванням обмежень руху тіл системи внаслідок дії в'язей. У перекладі цей принцип буде таким: «якщо на яку-небудь систему матеріальних тіл або точок діють якісь потенції і ця система знаходиться в стані рівноваги і якщо цій системі надати якийсь дуже малий рух, у результаті чого кожна точка системи пройде нескінченно малий простір, то сума потенцій, які помножені на простір, який точка прикладення потенцій пройде в напрямі дії цієї самої потенції, завжди буде дорівнювати нулю. При цьому шлях, пройдений точкою, треба вважати додатнім, якщо він співпадає з напрямом потенції, i вважати від'ємним у протилежному випадку». Видно, що узагальнені сили Лагранж не вважає векторами, в'язі він вважає ідеальними.

Можливо, що цей принцип може вважатися новою аксіомою, яка не $€$ наслідком законів Ньютона. Запропонований ученим підхід не вимагає ні механічних, ні геометричних міркувань, достатньо застосовувати алгебраїчні методи за шаблонним підходом.

Підхід Лагранжа буде коректним за дотримання низки умов: 1) система відліку повинна бути інерційною; 2) зв'язки між тілами в системі 
не повинні залежати від часу; 3) сума віртуальних робіт активних сил на всіх можливих переміщеннях повинна дорівнювати нулю.

Екстремальний підхід, який запропонував учений, характеризується низкою параметрів:

1. Значення масиву можливих переміщень та масиву узагальнених координат створюють два конфігураційні багатовимірні простори. 2. Для обґрунтування динаміки базовий характер мають поняття енергії. 3. Для обґрунтування динаміки базовий характер мають поняття імпульсу. 4. Для обгрунтування динаміки базовий характер мають поняття дії. 5. Використовується апарат варіаційного обчислення. 6. Тип детермінізму Ньютонівський.

Лагранжем в аналітичній механіці були запропоновані принципово нові поняття та нова розширена трактовка існуючих:

1) можливі переміщення; 2) узагальнені координати; 3) дія; 4) енергія; 5) імпульс; 6) принцип найменшої дії.

Учений вводить поняття «узагальненої координати» та відповідної їй «узагальненої сили», яка може бути силою, моментом сили і тому подібним. Узагальнена координата - це величина, яка характеризує положення тіл системи. Про цей принцип можна сказати, що він $€$ джерелом, з якого починається аналітична механіка. Про екстремальний принцип Лагранжа сучасники казали, що він став матір'ю аналітичної механіки, сама механіка стала розділом математичного аналізу, але не більше того.

Лагранж мав намір запропонувати прості загальні закони механіки, використовуючи ньютонівські базові засади. Він показав можливість одержання законів Ньютона із варіативного принципу. Механіка Лагранжа не конкурувала з механікою Ньютона, а навпаки, вона його доповнювала та додатково розвивала, вона разом із диференційним обчисленням використовувала варіаційне обчислення. У ній рух механічної системи описується за допомогою конфігураційного простору, складовими елементами якого є узагальнені координати, швидкості матеріальних тіл та час. Напрям руху визначається не векторами, як у механіці Ньютона, а точками конфігураційного простору. Функція Лагранжа $L$ визначається як різниця кінетичної $T$ та потенціальної енергії $U$, тобто $L=T-U$. Тоді Ньютонівську систему механіки можна розглядати як окремий випадок системи Лагранжа за умови, що конфігураційний простір - це простір Евкліда.

Для вільної матеріальної точки рівняння Лагранжа співпадають із рівняннями Ньютона. Необхідно підкреслити, що в Лагранжа принцип найменшої дії з'являвся вже як наслідок базових положень теорії (Лагранж, 1950).

Механіка Гамільтона характеризується принципово тим, що з самого початку базується на схожому екстремальному постулаті. Гамільтон у своїй праці використовував помітну аналогію між механікою та формальною 
теорією оптики свого часу, тобто це був прояв механіцизму. 3 варіаційного принципу Гамільтона легко одержати принцип Даламбера, який після цих пропозицій можна розглядати як теорему. Далі виводяться закони статики, закони збереження механічних величин. Механіка Гамільтона - це механіка в фазовому просторі узагальнених координат, імпульсів та часу. Вона дозволяє знаходити рішення таких задач, які не вдається розв'язати іншими методами - як, наприклад, рух небесних тіл у складних умовах чи визначення руху окремих деталей у складних механізмах (Ландау та Лифшиц, 1973).

Ця механіка дозволяє досить просто знайти зв'язок із квантовою механікою чи релятивістською механікою, що $є$ їі великою перевагою. У механіці Гамільтона міститься загальна для механіки система кінематичних та хронометричних понять та аксіом і евклідів простір. Вона містить силову функцію Гамільтона $\mathrm{H}$, яка дорівнює сумі кінетичної Т то потенціальної енергії U, тобто $\mathrm{H=T}+\mathrm{U}$.

Існують також теорії, у яких екстремальний принцип найменшої дії може розглядатись як наслідок із закону збереження енергії, але не всі дослідники з цим погоджуються.

Варіанти механіки Лагранжа і механіки Гамільтона використовують різний математичний апарат, використовують різний набір базових принципів, мають схожі погляди на природу та схожу сукупність об'єктів. Конкуренція між ними спостерігається в плані аналітики, методологічна конкуренція досить невелика, усі не виходять за межі механіки. Коли може закінчитися конкуренція між ними - незрозуміло. Існуючий математичний апарат поки що не надав переваг жодній із теорій. Засоби аналітичної механіки, особливо це стосується варіаційних принципів, значно ускладнюють підрахунок результатів, унаслідок чого роблять неможливим прогнозування наслідків, які можуть знайти застосування в технічній механіці та інженерних дисциплінах.

Механіка Ньютона базується на таких векторних поняттях, як вектор сили та вектор імпульсу. Механіка Лагранжа базується на скалярних поняттях: кінетичній енергії та силовій функції Лагранжа.

У випадку вивчення руху вільних частинок, на які не накладені в'язі, ці підходи за математичною складністю приблизно однакові. Якщо ж в'язі накладені, то метод Лагранжа більш простий у використанні тому, що в цьому випадку в'язі будуть ураховані природним шляхом, оскільки точки системи будуть рухатися лише вздовж таких траєкторій, які дозволені в'язями.

У механіці Ньютона треба враховувати також сили, які підтримують ці в'язі. Також треба зазначити, що третій закон Ньютона має певні обмеження - він справедливий лише під час вивчення руху твердого тіла. Другий закон Ньютона може коректно бути застосованим лише для одної матеріальної точки. Адже в випадку, коли матеріальна точка має зв'язок із іншими матеріальними точками, як це має місце в випадку рідини чи 
твердого тіла, яке деформоване, застосування другого закону вимагає уваги та вмінь при подоланні математичних проблем.

У механіці Лагранжа ми бачимо, що матеріальна точка $є$ частиною системи. Закони системи можна розглядати і як закони системи, і як закони структури. На систему діє лише одна силова функція, а не масив багатьох сил, незалежних одна від іншої, як у механіці Ньютона. Потрібно знати лише кінематичні умови в конкретній задачі.

Однак, силова функція Лагранжа нічого не може сказати про природу сили тертя. Урахування сили тертя має дуже важливе значення, тертя може бути дуже корисним, як, наприклад, у випадку сили зчеплення між злітною смугою аеродрому та резиною коліс шасі літака, або дуже шкідливим, у випадку тертя між деталями двигуна літака, які рухаються одна відносно іншої. Природа сили тертя залежить від природи міжмолекулярних процесів у матеріалах деталей, але це сфера інтересів іншої наукової дисципліни. Механіка Ньютона ці проблеми обходить.

Перевагою механіки Лагранжа також $є$ свобода при виборі будь-якої системи координат, у якій розглядається конкретна задача, тому що варіаційні методи задовольняють принципу інваріантності при переході від однієї системи координат до іншої. Механіка Ньютона без зайвих проблем розглядає вирішення задач лише в різних прямокутних системах координат Декарта. Перевагою механіки Лагранжа $€$ також те, що ми маємо справу з одним загальним принципом динаміки, стандартна процедура застосування якого дозволяє одержати всю необхідну систему рівнянь шляхом використання варіаційного методу. Варіаційний метод не пов'язаний із якоюсь конкретною системою координат і дозволяє одержати систему рівнянь за будь-якого вибору координат. У випадку механіки Ньютона ми отримуємо сотні різних видів диференційних рівнянь, знайдення рішень кожного окремого виду вимагає багато зусиль, які, разом із тим, не гарантують одержання коректного результату.

3 усього видно, що теорії Ньютона, Лагранжа та Гамільтона $\epsilon$ конкурентами в плані теоретичному, не $\epsilon$ повністю рівнозначними в емпіричному, дослідному плані, а в плані своєрідної «новомови» являються рівнозначними, всі мають фактично один і той зміст, якщо не говорити про силу тертя. Вони пов'язані базисними принципами та законами, мають багато спільного в кінематиці та в динаміці. Разом із тим видно, що дослідницькй фундамент механіки Лагранжа та Гамільтона значно більший, ніж механіки Ньютон. У перших двох теоріях перейшло багато інформації від оптики та її явищ, вони були згенеровані за аналогією з екстремальним принципом Ферма в оптиці.

У механіці Ньютона рух тіла здійснюється від одного моменту часу до іншого моменту часу, від однієї точки простору до іншої. У механіці Лагранжа та Гамільтона ми рух окремої матеріальної точки бачимо весь та 
зразу, цілком, у чотирьохвимірному просторі-часі. Не потрібно розглядати причино-наслідковий зв'язок. Закони руху базуються на моделі про багатоваріантність можливостей у процесі реалізації руху, взаємній єдності визначеності й невизначеності, стабільності та нестабільності, екстремальності і звичайності, багатоваріантності нереалізованих варіантів руху та одиничної варіантності реального руху.

Механіка Ньютона під час розгляду руху вважала за інваріанти динамічні величини - координати матеріальних точок та їх імпульси. Приводяться математичні формули для визначення положення матеріального тіла в різних системах координат, швидкості, прискорення, енергії, імпульсу, моменту імпульсу. Дуже важливим фактом $\epsilon$ те, що для замкнутих механічних систем вводяться закони збереження скалярної величини - енергії, двох векторних величин - імпульсу та моменту імпульсу.

Механіка Гамільтона динамічні величини розглядає як функції деяких параметрів канонічних перетворень, за якими знаходяться інваріанти більш глибинного, фундаментального рівня. Розвиток механіки в епоху після Ньютона залишив без змін їі емпіричний зміст, але по новому проаналізував ії потенціальні можливості, дозволив критично переглянути основи теорії. Деякі вчені вважали, що екстремальні принципи не містять нічого нового в порівнянні з законами Ньютона. Поява теорії відносності Ейнштейна показала великий потенціал варіаційних принципів та спростувала справедливість формалізму Ньютона в межах нової теорії.

Паралельне співіснування декількох варіантів класичної механіки $\epsilon$ наслідком взаємного проникнення фундаментальних принципів та тих законів, які з них витікають. Виразом внутрішнього зв'язку механічних теорій $\epsilon$ те, що базові закони можуть бути одержані 3 варіаційного принципу, який має однакове формулювання для всіх базових теорій. Можливо, що було $б$ краще для глобального розвитку класичної механіки досягти єдності між існуючими напрямами.

Механіка розвивалася протягом довгого часу, шлях іï розвитку був складний. Можна вважати, що теорія відносності Ейнштейна була логічним завершенням ери розвитку класичної механіки. Після цього з неї почали відокремлюватися окремі їі частини, які стали незалежними науковими дисциплінами, як, наприклад, квантова механіка чи релятивістська механіка.

Проблеми з розумінням природи гравітації були навіть у видатних мислителів. Ейнштейн створив у свій час свою теорію гравітації, назвавши ії̈ «Загальна теорія відносності». Він прийняв як аксіому рівність між собою інерційної та гравітаційної мас, із його точки зору це два різних прояви однієї і тієї самої властивості матеріальних тіл. Масу вчений трактував як прояв різної міри кривизни простору.

Далеко не всі визнані фахівці згодні з теорією Ейнштейна. Згідно з останніми науковими даними, за прояв маси в природі відповідальний так 
званий «бозон Хіггса (Higgs boson)», одна з елементарних частинок. Цікаві результати в поясненні законів гравітації одержала сучасна теорія «суперструн», ведуться роботи з розробки квантової теорії гравітації.

У наш час багато вчених працюють над створенням Єдиної теорії поля, $€$ певні успіхи на цьому шляху. У разі створення завершеної Єдиної теорії поля, можливо, з'явиться чітке розуміння явищ гравітації. Механіка в останній час переживає низку проблем у своєму розвиткові, основна проблема - це відсутність сучасних концепцій, які змогли би забезпечити бурхливий розвиток на зразок того, що відбувався в епоху Ньютона. Пуанкаре свого часу запропонував використовувати, як базові положення, адіабатичні інваріанти, теорію стійкості, теорію диференційних рівнянь, теорію фазових просторів.

У спробах прогнозування подальших шляхів розвитку механіки можна сказати, що науково-технічний прогрес останніх років відкриває нові можливості перед класичною механікою, з розвитком комп'ютерної техніки вона стала дедалі ширше застосовуватися в механіці як класичній, так і в технічній, шляхом використання потужних EOM, з використанням напрацьованих пакетів комп'ютерних програм, дозволяє ефективно вирішувати складні проблеми як механіки, так і значної кількості суміжних технічних дисциплін, наприклад, застосувати нові методи розрахунку металічних ферм для будівництва. Також триває процес зі створення технічних та прикладних галузей у науково-технічній сфері шляхом створення нових теоретичних засад як на базі механіцизму, як це вже було раніше, так і інших підходів. Еволюція механіки, як ніщо інше, наочно демонструє, що будь-яка наукова теорія або деякі її складові частини, не можуть бути абсолютно замкнуті та обмежені своїми вузькими початковими кордонами (История механики в России, 1987). Теорії завжди взаємно впливають одна на іншу, що веде до взаємного доповнення.

Висновки. Механіка є чимось більшим, ніж просто відображенням властивостей та законів природи. Вона являє собою важливий метод наукового дослідження. Це теорія, яка підтверджена дослідом, вона потім використовується для одержання нових знань про світ. Науковий метод $\epsilon$ концентратом базового змісту одержаних знань, їх принципових особливостей, фундаментальних законів розвитку. Наукова теорія виникає на невеликій множині наукових фактів, потім вона прагне до розширення меж свого застосування й починає використовуватися для пояснення все ширшого кола явищ (Готт, 1988).

Розширюючи зону свого застосування, теорія поступово починає змінюватися сама, запозичуючи нові підходи в конкуруючих теорій. Цю інформацію необхідно донести до студентів на заняттях. 


\section{ЛІТЕРАТУРА}

Границкая, А. С. (1991). Научиться думать и действовать: Адаптивная система обучения в школе: книга для учителя. М.: Просвещение (Granitskaia, A. S. (1991). Learning to think and act: An adaptive learning system at school: a book for the teacher. M.: Education).

Дьяченко, В. К. (1989). Организачионная структура учебного прочесса и ее развитие. М.: Педагогика (Diachenko, V. К. (1989). The organizational structure of the educational process and its development. M.: Pedagogy).

Талызина, Н. Ф. (1975). Управление процессом усвоения знаний. М.: Издательство Московского Университета (Talyzina, N. F. (1975). Management of knowledge acquisition process. M.: M oscow University Press).

Унт, И. э. (1990). Индивидуализация и дифреренциация обучения. М.: Педагогика (Unt, I. E. (1990). Individualization and differentiation of training. M.: Pedagogy).

Шадриков, В. Д. (2014). Мысль и ее познание. М: Логос (Shadrikov, V. D. (2014). Thought and its cognition. $M$ : Logos).

Готт, В. С. (1988). Философрские вопросы современной физики. М.: Высш. шк. (Gott, V. S. (1988). Philosophical issues of modern physics. M.: Higher school).

История механики с конца XVIII века до середины XX века (1972). Ашот Григорян и Б. Погребысский (ред.). М.: Наука (The history of mechanics from the end of the 18th century to the middle of the 20th century (1972). Ashot Grigorian and B. Pogrebysky (Eds.). M.: Science).

Веселовский, И. Н. (1974). Очерки по истории теоретической механики. М.: Высш. школа (Veselovsky, I. N. (1974). Essays on the history of theoretical mechanics. M.: Higher school).

История механики в России (1987). А. Н. Боголюбов, И. З. Штокало, Э. Г. Цыганкова и др. (ред.). Киев: Наукова думка (History of mechanics in Russia (1987). A. N. Bogoliubov, I.Z. Shtokalo, E. G. Tsygankova et al. (Ed.). Kyiv: Naukova Dumka).

Декарт, Р. (1989). Сочинения: в 2-х т. М.: Мысль (Descartes, R. (1989). Works: in 2 volumes. M.: Thought).

Эйлер, Л. (1934). Новая теория движения Луны - Theoria motuum Lunae, nova methodo perfoctata. л.: AH CCCP (Euler, L. (1934). The New Theory of Moon Movement Theoria motuum Lunae, nova methodo perfoctata. L.: USSR Academy of Sciences).

Лагранж, Ж. (1950). Аналитическая механика: т. 2. М.: Гостехиздат (Lagrange, J. (1950). Analytical mechanics: Vol. 2. Moscow).

Ньютон, И. (1989). Математические начала натуральной философии. М.: Наука (Newton, I. (1989). Mathematical principles of natural philosophy. M.: Science).

Ландау, Л. Д., Лифшиц, Е. (1973). Теоретическая физика. М.: Наука (Landau, L. D., Lifshits, E. (1973). Theoretical physics. M.: Science).

\section{PEЗЮME}

Королёв Сергей. Развитие методики преподавания механики как борьба вариативного и ньютоновского подходов.

Очередная статья цикла, в котором изучается улучшение методики преподавания механики. Предлагается комплексный подход преподавания механики, в котором используется многомерный массив из нескольких базисных положений, которые комбинируются между собой по комбинаторному принципу, в зависимости от конкретной ситуации, создавая широкое поле возможностей. К минимальному уровню набора положений предлагается добавить рассмотрение развития механики как борьбы и сотрудничества подходов Ньютона, который использовал обобщение громадного числа наблюдений и опытов, и вариативных подходов 
Лагранжа и Гамильтона, которые берут свое начало фрактически в оптике, являя собой удачно угаданный постулат. Ясно, что одновременное применение нескольких инструментов будет ускорять достижение цели.

Ключевые слова: методика преподавания механики, вариативный подход, метод Лагранжа, метод Гамильтона, диалектическое взаимодействие, парадигма Ньютона.

\section{SUMMARY}

Koroliov Serhii. Development of teaching mechanics as a struggle of variational and Newtonian approaches.

A comprehensive approach to teaching mechanics is proposed, which uses a multidimensional array of several basic positions that are combined with each other according to a particular situation.

Newton's mechanics is based on the laws of motion, which are described by differential equations. Fermat offered, at one time, his variant of the extreme principle, which, at the same time, contradicted the principles of Newtonian mechanics. Attempts to build the mechanics on the principle of least action made Euler and Maupertuis, but they cannot be called successful. D'Alembert suggested that the problems of dynamics, in determining the laws of motion, should be reduced to the problems of static, which considers the case of motionless bodies. Lagrange continued development of analytical mechanics in order to reduce mechanics and methods of solving its problems to formulas of general form.

It is easy to obtain the d'Alembert principle from the Hamiltonian variational principle. This mechanics makes it quite easy to find a connection with quantum mechanics or relativistic mechanics, which is its great advantage.

There are also theories in which the extreme principle of least action can be considered as a consequence of the law of conservation of energy, but not all researchers agree with it.

Newtonian mechanics is based on vector concepts such as force vector and momentum vector. Lagrangian mechanics is based on scalar concepts: kinetic energy and Lagrangian power function. Newtonian mechanics must also take into account the forces that support the link.

The advantage of Lagrangian mechanics is freedom to choose any coordinate system. The advantage of Lagrangian mechanics is that we are dealing with one general principle of dynamics, the standard procedure of which allows to obtain all the necessary system of equations by using the variational method. In Newtonian mechanics, the movement of the body is from one point in time to another point in time, from one point of space to another. In the mechanics of Lagrange and Hamilton, we see the movement of a separate material point all at once, completely, in four-dimensional space-time.

The Newtonian mechanics, when considering motion, considered invariants dynamic quantities - coordinates of material points and their impulses. The dynamic of Hamiltonian mechanics is regarded as a function of some parameters of canonical transformations, behind which are the invariants of a deeper, more fundamental level.

Poincare at one time proposed to use as base positions adiabatic invariants, stability theory, differential equation theory, phase space theory.

Key words methods of teaching mechanics, variational approach, Lagrange method, Hamilton method, dialectical interaction, Newton's paradigm. 